\title{
Phenology of overland dispersal in the invasive crayfish Faxonius immunis (Hagen) at the Upper Rhine River area
}

\author{
Alexander Herrmann*, Adam Schnabler and Andreas Martens \\ Institute of Biology, University of Education Karlsruhe, Bismarckstraße 10, 76133 Karlsruhe, Germany
}

\begin{abstract}
The non-indigenous crayfish Faxonius immunis (Hagen) is the dominant crayfish species at the Upper Rhine River system since his detection in 1993. As an invasive alien species, it is one of the biggest threats to aquatic biodiversity in the area. By dispersing over land, the species has a high potential to colonize small ponds created for threatened amphibians and dragonflies. Shortly after invasion, the fast growing population of $F$. immunis is changing the habitat drastically. In June 2016, our team started a local information campaign including citizen science project where the local people south of Karlsruhe, BadenWuerttemberg, Germany, could contact us when they spot a crayfish migrating over land to assess the activity of overland dispersal on a regional scale. Until January 2018, we got a total of 98 responses. Thirtynine include suitable information including 33 records of overland dispersal of $F$. immunis. The species was recorded on land throughout the year, except February and July. Additionally, single observations of overland dispersal of other invasive crayfish species, naming Procambarus clarkii (Girard), Pacifastacus leniusculus (Dana), Procambarus virginalis (Lyko) and Faxonius limosus (Rafinesque), were recorded.
\end{abstract}

Keywords: amphibian conservation / citizen science / management / biological invasions / non-indigenous species

Résumé - Phénologie de la dispersion terrestre de l'écrevisse envahissante Faxonius immunis (Hagen) dans la région du Rhin Supérieur. L'écrevisse non indigène Faxonius immunis (Hagen) est l'espèce d'écrevisse dominante dans le système du Rhin supérieur depuis sa détection en 1993. En tant qu'espèce exotique envahissante, c'est l'une des plus grandes menaces pour la biodiversité aquatique de la région. En se dispersant sur la terre ferme, l'espèce a un fort potentiel de colonisation des petits étangs créés pour les amphibiens et les libellules menacés. Peu après l'invasion, la population à croissance rapide de $F$. immunis change radicalement l'habitat. En juin 2016, notre équipe a lancé une campagne d'information locale comprenant un projet de science citoyenne où les habitants du sud de Karlsruhe, Bade-Wurtemberg, en Allemagne, pouvaient nous contacter lorsqu'ils repéraient une écrevisse migrant sur terre pour évaluer l'activité de dispersion terrestre à l'échelle régionale. Jusqu'en janvier 2018, nous avons reçu un total de 98 réponses. Trente-neuf d'entre elles comprennent des informations appropriées, y compris 33 dossiers de dispersion terrestre de $F$. immunis. L'espèce a été enregistrée sur terre tout au long de l'année, sauf en février et juillet. De plus, des observations uniques de dispersion terrestre d'autres espèces envahissantes d'écrevisses, nommant Procambarus clarkii (Girard), Pacifastacus leniusculus (Dana), Procambarus virginalis (Lyko) et Faxonius limosus (Rafinesque), ont été enregistrées.

Mots-clés : conservation des amphibiens / science citoyenne / gestion / invasions biologiques / espèces non-indigènes.

\section{Introduction}

Crayfish are known to be able to disperse moving over land (Braswell and Cooper, 1995), however, the potential and the annual phenology are based on accidental records only. Knowledge about the time period and factors influencing this

\footnotetext{
${ }^{*}$ Corresponding author: alexander.herrmann@ph-karlsruhe.de
}

behavior may support new management approaches. Banha and Anastácio (2014) studied the desiccation survival capacities of Pacifastacus leniusculus (Lyko) and Procambarus clarkii (Girard), as they are invasive at the Iberian Peninsula and disperse overland. Additionally, P. clarkii is known to show higher overland dispersal activity correlated to relative humidity (Ramalho and Anastácio, 2015). As invasive alien crayfish species (IACS) are known to be a threat to amphibians, overland dispersal can cause serious problems in 
conservation areas or breeding habitats for amphibians (Nyström, 1997; J Cruz et al., 2006; Cruz and Segurado, 2008). Omnivorous crayfish are key species in aquatic ecosystems, but IACS became a serious problem around the world, as invasive alien species turned out to be one of the biggest threats to biodiversity (Butchart et al., 2010; Lodge et al., 2012; Richardson et al., 2013). Managing them in an area means to combine as many different methods as there are known to minimize the further spread of the species (Gherardi et al., 2011).

The Upper Rhine River area is a hotspot to biodiversity in Central Europe (Ackermann and Sachteleben, 2012). Threatened amphibians as Triturus cristatus (Laurenti), Rana arvalis Nilsson and Hyla aborea (Linnaeus) are being supported by government and NGO-funded newly created ponds for nature conservation. The invasive, North American freshwater crayfish Faxonius immunis (Hagen) is colonizing these habitats by overland dispersal, forming new threat to amphibians. The species was known as Orconectes immunis (Hagen) until now. We follow the recent classification of crayfish by Crandall and De Grave (2017) and named it $F$. immunis (Hagen). The first population was detected in 1993 near the Baden Airpark (Gelmar et al., 2006). Since then, $F$. immunis spread north along the Rhine system through canals, ditches and streams and is still colonizing aquatic systems from the floodplain to the slope of the Black Forest (Chucholl, 2012). F. immunis grows high population densities in temporary and muddy ponds and can survive dry periods by building burrows (Tack, 1941; Bovbjerg, 1970; Martens, 2016). Juvenile $F$. immunis grow fast in their first year, needing a higher amount of protein in their diet than adult ones (Brown and Wetzel, 1993; Chucholl, 2012; Herrmann, 2017). The adults mainly feed on macrophytes and are decreasing hideouts for insects or aquatic vertebrates (Coler and Seroll, 1975). By moving overland, F. immunis invaded ponds and lakes which are not directly connected to streams and ditches of the River Rhine system. Understanding the ability to disperse overland could be a key to protect systems not yet colonized by this species and, especially, to give advice to those who are planning to create new artificial ponds for amphibian conservation. As the amount of IACS in Europe is rising, every information on overland dispersal can be crucial for the protection of other waters. Resulting in the lack of knowledge about factors influencing the behavior to disperse overland, a citizen science project has been started.

\section{Material and methods}

In collaboration with local administrations, forty-seven information boards (Fig. 1) were installed between June and August 2016. Along the River Rhine, a stretch of approximately $50 \mathrm{~km}$ was covered. The boards were placed from the city of Rheinstetten in the north and to the Baden-Airpark in the south next to areas where populations of F. immunis are known along pathways (Fig. 2).

The German text on the installed boards is translated in the following: "Crayfish wanted! The North American calico crayfish is spreading along the Upper Rhine River region. With the ability to move over land, it is colonizing several ponds and lakes. Therefore, the crayfish prefers easy routes, e.g. our

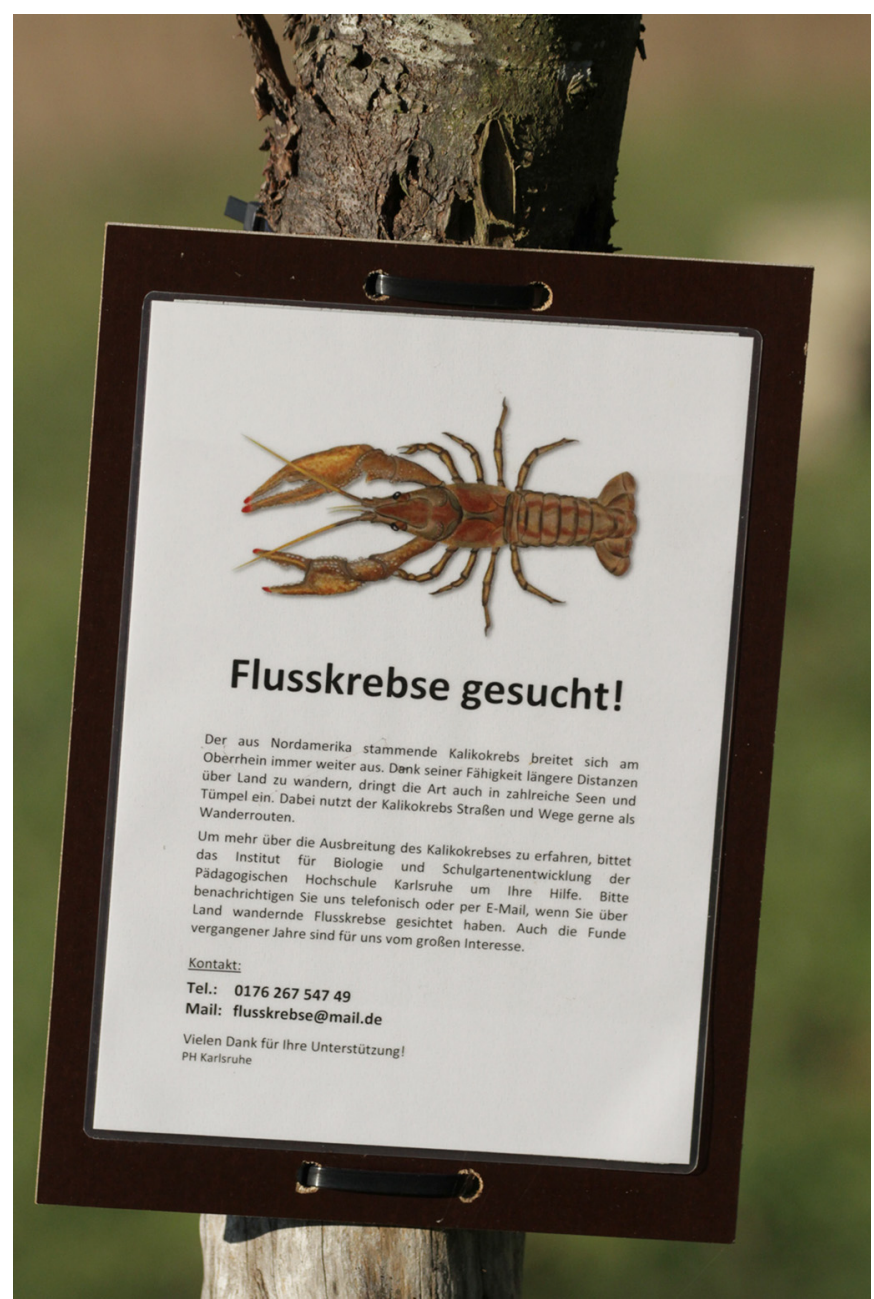

Fig. 1. Information board.

streets or paths. To learn more about the spread of the calico crayfish, the Institute for Biology, University of Education Karlsruhe, asks for your help. Please contact us via email or telephone if you see crayfish moving over land. In addition, knowledge about earlier contact with crayfish migrating over land are of interest. Contact: flusskrebse@mail.de, 017626754749 Thank you for your support!"

To support the project, articles in local newspapers were published shortly after installing the tables. The articles were published again later to keep them in focus.

The bigger part had taken reports on crayfish seen inside the water and emails with questions and suggestions about crayfish species in the area. Out of 98 emails sent to us 39 have been suitable for our study. Information sent to us was checked by evaluating the attached photos and comparing the described locality with our data base on the distribution of $F$. immunis. For further analysis, emails with (PIC: examples in supplementary material Fig. S1) and without (NPIC) attached photos were separated. The date of observation was taken from the EXIF data in the attached photos. All records apply to stray findings.

We compared these data with those from master theses and exam works reported quantitative short time data at three ponds in the city of Rheinstetten $\left(48^{\circ} 58^{\prime} 17.04^{\prime \prime} \mathrm{N}\right.$; $\left.8^{\circ} 17^{\prime} 44.394^{\prime \prime} \mathrm{E}\right)$, where the overland migration ability was 


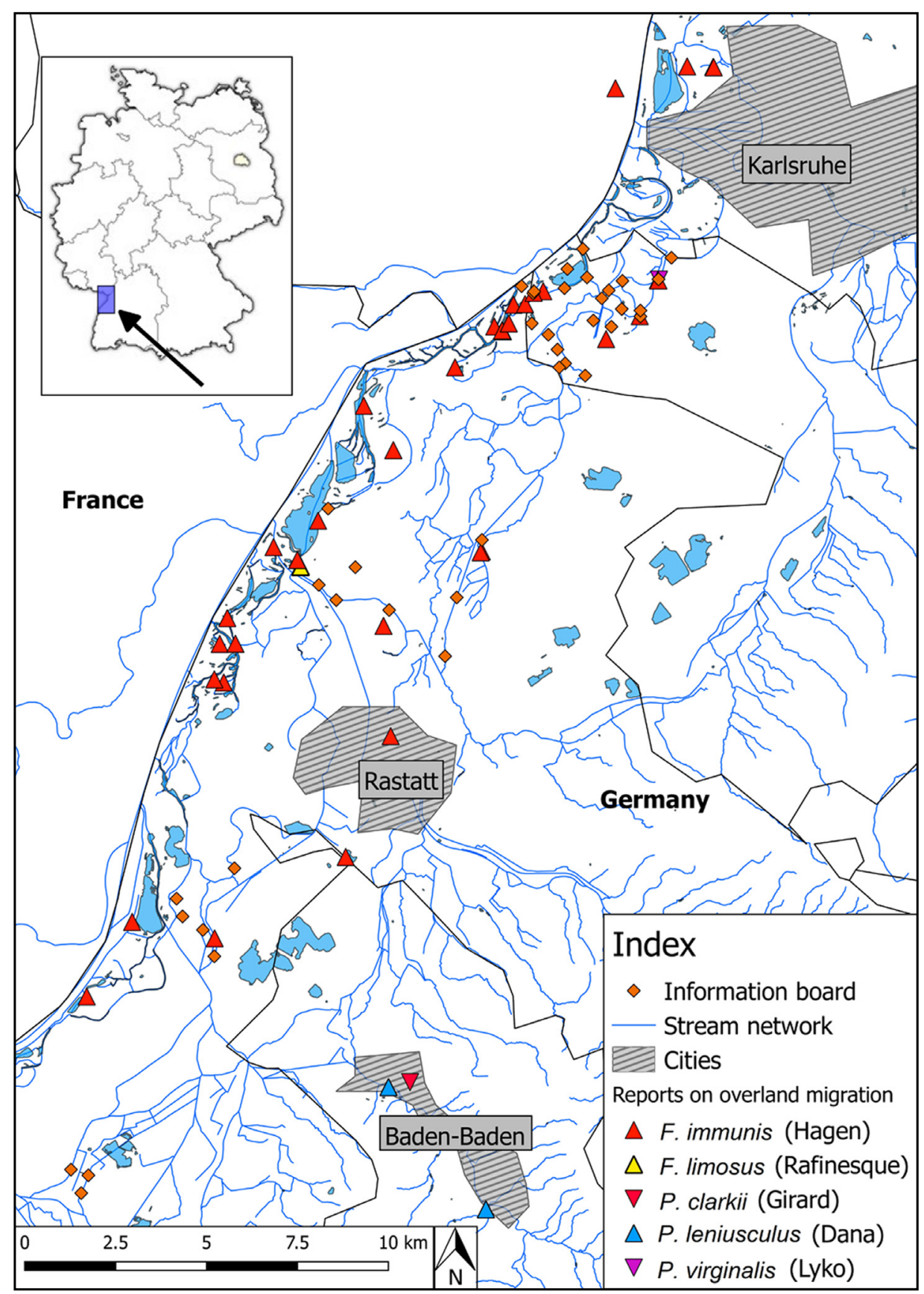

Fig. 2. Map of the River Rhine system with reports of overland dispersal of crayfish recorded by citizen scientists.

evaluated. Data was provided from the periods of 23.04.2015 to $22.05 .2015,30.10 .2015$ to 31.05 .2016 (Schnabler, 2016) and 23.02.2017 to 30.04.2017 (Marholtz, 2017), respectively.

\section{Results}

We got a total of 39 reports, 33 reports telling F. immunis seen migrating over land. One report had no exact date to note and five turned out to be other crayfish species. In total, $19 \mathrm{~F}$. immunis could be identified by the photo sent to us (PIC), 14 emails had no attached photo while telling $F$. immunis would have been seen (NPIC). The data shows that this species can disperse overland throughout the whole year with peaks in spring and autumn (Fig. 3). Unpublished data from master theses and exam works reported quantitative short-time data, which follows the same implication (Fig. 4).

The reports of $F$. immunis migrating overland were from the area covered with information boards, and some additional from adjacent areas (Fig. 2). The furthest was more than $15 \mathrm{~km}$ far away from the nearest board, but the received picture was showing another crayfish species.

Four other IACS could be identified moving outside the water within the PIC-data: Faxonius limosus (Rafinesque), $P$. leniusculus (Dana), Procambarus virginalis (Lyko) and $P$. clarkii (Girard). 


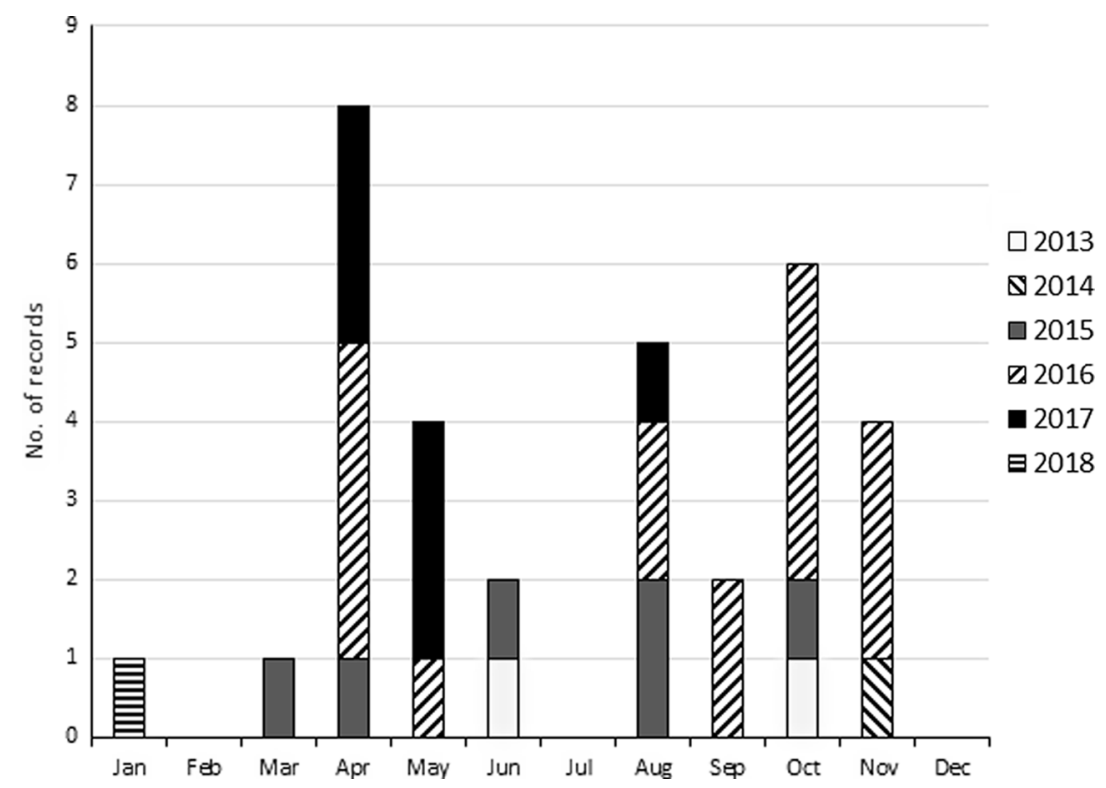

Fig. 3. Total received data on $\mathrm{F}$. immunis (Hagen) migrating overland $(\mathrm{n}=33)$ divided by years of record.

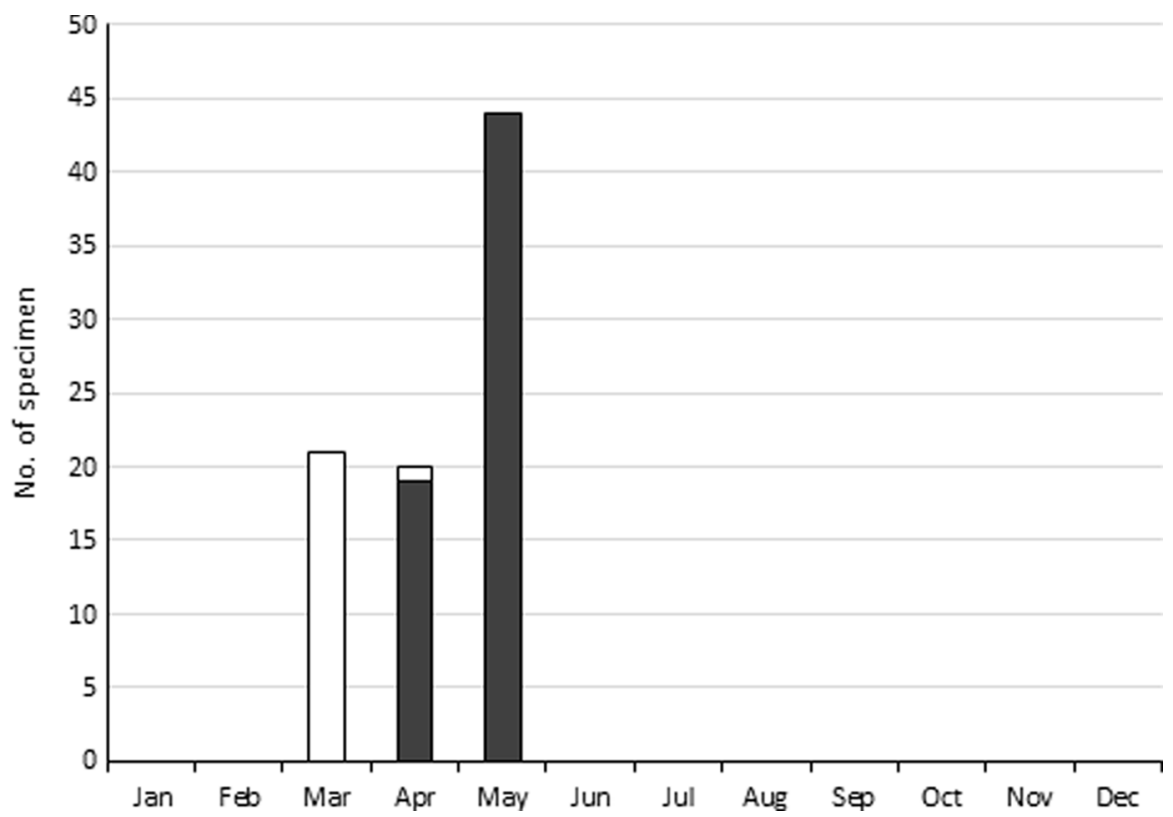

Fig. 4. Data on overland migration of F. immunis (Hagen) $(n=85)$ collected in unpublished master theses and exam works in the years 2015 , 2016 (Schnabler, 2016, black) and 2017 (Marholtz, 2017, white), respectively.

One dataset was not included in the analysis: In October 2016, within the village of Elchesheim-Illingen $\left(48^{\circ} 55^{\prime}\right.$ $52.748^{\prime \prime} \mathrm{N} ; 8^{\circ} 12^{\prime} 38.541^{\prime \prime} \mathrm{E}$ ), six individuals of $F$. immunis were collected by children on the road, just after excavated earth from a dredged ditch was placed at the edge of the village.

\section{Discussion}

Citizen science studies grew more important in the past decade. They are well-established methods for ornithologists to collect data on migration seasons, habitat use or distribution as important ecological information in larger regions
(Greenwood, 2007). Crall et al. (2010) could show that the highest amount of citizen science studies on invasive species aimed for presence or absence. These variables are easy to check and do not require much scientific knowledge. Collectively, citizen science studies show the potential to collect extensive data at low costs across large areas (Dickinson et al., 2010). For crayfish distribution, Perdikaris et al. (2017) have shown that citizen science data could provide useful data on presence and distribution of species. In our project, we wanted to collect data on the so far badly known phenology of overland dispersal as well as new data on distribution of F. immunis. 
Our data clearly demonstrates that $F$. immunis is dispersing over land the entire year. The analysis from the PIC suggests that $F$. immunis has two seasons of higher activity in overland dispersal. The NPIC and the unpublished data from the master theses and exam works support this. The highest activity is between March and May, during the spawning season of this species. The other season of high activity is between September and November, when $F$. immunis is mating. So far, no activity is reported for December, February and July. We suppose that F. immunis leaves out extreme cold or dry periods of the year because the warmest month of the year at the Upper Rhine River area is July. The seasonality could therefore occur out of abiotic factors like dewy weather or rainfalls in combination with the right temperature, just as Ramalho and Anastácio (2015) have shown it for P. clarkii, which shows higher overland dispersal activity above $70 \%$ relative humidity and between a temperature range of $16.3-24.2{ }^{\circ} \mathrm{C}$. As overland dispersal seems to depend on microclimate conditions, it could be supportive that the Upper Rhine River area shows the lowest amount of cold days in Germany (Heinemann, 2007). This should be investigated in a more focused study on the relative humidity and other meteorological effects. Another factor for seasonality could be the chance to colonize new habitats after mating or before spawning, because ovigerous females of $F$. immunis are taking the risk of moving over land, too (Schnabler, 2016, unpublished).

The knowledge about mechanisms in the dispersal of invasive crayfish, such as $F$. immunis, can lead to advanced management suggestions for the creation of new artificial ponds for amphibian conservation to minimize the spread of the species and their impact on the local ecosystem. Ponds should be protected by barriers like toad fences, where amphibians must be taken over it manually or with a permanent barrier, which is passable for amphibians but not for crayfish (Schnabler, 2016). Further and existing data on overland dispersal of $F$. immunis can also be used to identify main dispersal routes and areas of high activity, which lead to highly populated systems. Isolating these systems and closing the corridors can be a key method to minimalize the further spread of the species.

Resulting in his broad tolerance towards pollution and habitats (Holdich, 2002; Chucholl, 2012) and his invasive potential (Karatayev et al., 2009) linked to his strongly rselected life history (Martens, 2016), we suggest that most existing ponds and lakes at the Upper Rhine River area could be colonized by $F$. immunis in the next 10 years. This prediction is supported by knowledge gained about $P$. clarkii in the southwest of the Iberian Peninsula (Cruz and Rebelo, 2007), where the crayfish also disperse overland frequently.

\section{Supplementary Material}

The Supplementary Material is available at http://www. kmae-journal.org/10.1051/kmae/2018018/olm.

Acknowledgements. We would like to thank all citizen scientists for participating in our study and providing us with data. We are indebted to S. Eisenbarth for providing the board material and for helping us installing it. We appreciate the help of R. Hertweck for organizing and installing boards in the southern areas. Further thank should go to the students $\mathrm{C}$. Marholtz, S. Wentz and A. Wilberts for providing additional data on overland migration. The study would not have been possible without the help of the local administrations and newspapers. We appreciate the helpful suggestions and comments made by our two independent reviewers. This study is supported by the nature conservation foundation of Baden-Wuerttemberg with earmarked funds from lottery (ID: 73-8831.21/546 91-1744GL).

\section{References}

Ackermann W, Sachteleben J. 2012. Identifizierung der Hotspots der Biologischen Vielfalt in Deutschland, BfN-Skripten 315: 1-133.

Banha F, Anastácio PM. 2014. Desiccation survival capacities of two invasive crayfish species. Knowl Manag Aquat Ecosyst 413: 01.

Bovbjerg RV. 1970. Ecological isolation and competitive exclusion in two crayfish (Orconectes virilis and Orconectes immunis). Ecology 51: 225-236.

Braswell AL, Cooper JE. 1995. Observations on North Carolina Crayfishes (Decapoda: Cambaridae). Brimleyana 22: 87-132.

Brown PB, Wetzel JE. 1993. Growth and survival of juvenile Orconectes virilis and Orconectes immunis at different temperatures. J World Aquac Soc 24: 339-343.

Butchart SHM, Walpole M, Collen B, van Strien A, Scharlemann JPW, Almond REA, Baillie JEM, Bomhard B, Brown C, Bruno J, Carpenter KE, Carr GM, Chanson J, Chenery AM, Csirke J, Davidson NC, Dentener F, Foster M, Galli A, Galloway JN, Genovesi P, Gregory RD, Hockings M, Kapos V, Lamarque J-F, Leverington F, Loh J, McGeoch MA, McRae L, Minasyan A, Hernández Morcillo M, Oldfield TEE, Pauly D, Quader S, Revenga C, Sauer JR, Skolnik B, Spear D, Stanwell-Smith D, Stuart SN, Symes A, Tierney M, Tyrrell TD, Vié J-C, Watson R. 2010. Global biodiversity: indicators of recent declines. Science 328: 1164-1168.

Chucholl C. 2012. Understanding invasion success: life-history traits and feeding habits of the alien crayfish Orconectes immunis (Decapoda, Astacida, Cambaridae). Knowl Manag Aquat Ecosyst 404: 04.

Coler RA, Seroll A. 1975. Demonstrated food preferences of Orconectes immunis (Hagen) (Decapoda, Astacidae). Crustaceana 29: 319-320.

Crall AW, Newman GJ, Jarnevich CS, Stohlgren TJ, Waller DM, Graham J. 2010. Improving and integrating data on invasive species collected by citizen scientists. Biol Invasions 12: 3419 3428.

Crandall KA, De Grave S. 2017. An updated classification of the freshwater crayfishes (Decapoda: Astacidea) of the world, with a complete species list. J Crustac Biol 37: 615-653.

Cruz MJ, Rebelo R. 2007. Colonization of freshwater habitats by an introduced crayfish, Procambarus clarkii, in Southwest Iberian Peninsula. Hydrobiologia 575: 191-201.

Cruz MJ, Segurado P. 2008. Collapse of the amphibian community of the Paul do Boquilobo Natural Reserve (central Portugal) after the arrival of the exotic American crayfish Procambarus clarkii. Herpetol $J$ 18: 197-204.

Dickinson JL, Zuckerberg B, Bonter DN. 2010. Citizen science as an ecological research tool: challenges and benefits. Annu Rev Ecol Evol Syst 41: 149-172. 
Gelmar C, Pätzold F, Grabow K, Martens A. 2006. Der Kalikokrebs Orconectes immunis am nördlichen Oberrhein: ein neuer amerikanischer Flusskrebs breitet sich schnell in Mitteleuropa aus. Lauterbornia 56, 15-25.

Gherardi F, Aquiloni L, Diéguez-Uribeondo J, Tricarico E. 2011. Managing invasive crayfish: is there a hope? Aquat Sci 73: 185200.

Greenwood JJD. 2007. Citizens, science and bird conservation. $J$ Ornithol 148: 77-124.

Heinemann H-J. 2007. Eine Winterchronik: die Kälte der Winter in Deutschland von 1960/61 bis 2007/08, Deutscher Wetterdienst, Offenbach am Main, Berichte des Deutschen Wetterdienstes, p. 232.

Herrmann A. 2017. Laborversuche zum Einfluss der Nahrungszusammensetzung auf die Jugendentwicklung des Flusskrebses Orconectes immunis. In: Deutsche Gesellschaft für Limnologie edn., Erweiterte Zusammenfassung der Jahrestagung 2016, Hardegsen, pp. 40-45.

Holdich DM. (ed.), 2002. Biology of freshwater crayfish. (Oxford): Blackwell Science Ltd.

J Cruz M, Rebelo R, G Crespo E. 2006. Effects of an introduced crayfish, Procambarus clarkii, on the distribution of south-western Iberian amphibians in their breeding habitats. Ecography 29: 329338.

Karatayev AY, Burlakova LE, Padilla DK, Mastitsky SE, Olenin S. 2009. Invaders are not a random selection of species. Biol Invasions 11: 2009-2019.

Lodge DM, Deines A, Gherardi F, Yeo DCJ, Arcella T, Baldridge AK, Barnes MA, Chadderton WL, Feder JL, Gantz CA, Howard GW, Jerde CL, Peters BW, Peters JA, Sargent LW, Turner CR, Wittmann
ME, Zeng Y. 2012. Global introductions of crayfishes: evaluating the impact of species invasions on ecosystem services. Annu Rev Ecol Evol Syst 43: 449-472.

Marholtz C. 2017. Flusskrebse gehen auch an Land - Von eigenen Untersuchungen zum Unterrichtskonzept. Wissenschaftliche Hausarbeit, Pädagogische Hochschule Karlsruhe, Karlsruhe. (unpublished).

Martens A. 2016. Der Kalikokrebs - eine wachsende Bedrohung für Amphibien und Libellen am Oberrhein. Naturschutzinfo 2016: 24 26.

Nyström P. 1997. Crayfish predation on amphibian eggs and larvae. Amphibia-Reptilia 18: 217-228.

Perdikaris C, Konstantinidis E, Georgiadis C, Kouba A. 2017. Freshwater crayfish distribution update and maps for Greece: combining literature and citizen-science data. Knowl Manag Aquat Ecosyst 418: 51.

Ramalho RO, Anastácio PM. 2015. Factors inducing overland movement of invasive crayfish (Procambarus clarkii) in a ricefield habitat. Hydrobiologia 746: 135-146.

Richardson A, Reynolds JD, Souty-Grosset C. 2013. Ecological roles of crayfish in freshwater and terrestrial habitats. Freshw Crayfish 19: $197-218$.

Schnabler A. 2016. Die Überlandwanderung des Kalikokrebses Orconectes immunis: Untersuchungen meteorologischer und räumlicher Apsekte bei der Besiedlung von Kleingewässern. Master Thesis, Pädagogische Hochschule Karlsruhe, Karlsruhe. unpublished.

Tack PI. 1941. The life history and ecology of the crayfish Cambarus immunis Hagen. Am Midl Nat 25: 420-446.

Cite this article as: Herrmann A, Schnabler A, Martens A. 2018. Phenology of overland dispersal in the invasive crayfish Faxonius immunis (Hagen) at the Upper Rhine River area. Knowl. Manag. Aquat. Ecosyst., 419, 30. 